\title{
Mechanisms contributing to low domoic acid uptake by oysters feeding on Pseudo-nitzschia cells. II. Selective rejection
}

\author{
Luiz L. Mafra Jr. ${ }^{1,2, *}$, V. Monica Bricelj ${ }^{3}$, J. Evan Ward ${ }^{4}$ \\ ${ }^{1}$ Institute for Marine Biosciences, National Research Council, 1411 Oxford St., Halifax, Nova Scotia B3H 3Z1, Canada \\ ${ }^{2}$ Department of Biology, Dalhousie University, Halifax, Nova Scotia B3H 4J1, Canada \\ ${ }^{3}$ Institute of Marine and Coastal Sciences, Rutgers University, 93 Lipman Dr., New Brunswick, New Jersey 08901, USA \\ ${ }^{4}$ Department of Marine Sciences, University of Connecticut, 1080 Shennecossett Rd., Groton, Connecticut 06340, USA
}

\begin{abstract}
Oysters accumulate relatively low levels of domoic acid (DA) compared to other bivalves. Mafra et al. (2009, in this Theme Section) identified feeding mechanisms of oysters that may lead to low DA accumulation during monospecific blooms of Pseudo-nitzschia multiseries. However, several different species of Pseudo-nitzschia, as well as other diatoms and flagellates, may co-occur during a bloom. Therefore, the present study investigates pre-ingestive feeding processes that operate when oysters Crassostrea virginica are exposed to mixed phytoplankton assemblages containing $P$. multiseries of varying cell length. Guided by video-endoscopy, material transported along the ventral and dorsal gill tracts was sampled and analyzed to determine the site for sorting of microalgae on the pallial organs. There was no preferential rejection of $P$. multiseries in pseudofeces when oysters were exposed to the alga in a mixed suspension with other diatom species (Thalassiosira weissflogii or Chaetoceros muelleri). In contrast, P. multiseries was preferentially rejected when mixed with the flagellates Isochrysis galbana or Rhodomonas lens, suggesting a qualitative mechanism for particle sorting. This occurred on the gills, followed by further selection on the palps. Oysters also preferentially rejected larger $P$. multiseries cells $(82$ to $90 \mu \mathrm{m})$ relative to smaller ones $(24$ to $28 \mu \mathrm{m})$ on the gills, while no further selection based on size occurred on the palps. This effect is attributed to the fact that $P$. multiseries cells with a length that exceeds the width of the principal filament aperture (ca. $68 \mu \mathrm{m}$ ) are more likely directed to the ventral tract and rejected in pseudofeces. These findings offer an additional explanation for the relatively low DA levels found in oysters during natural Pseudo-nitzschia spp. blooms.
\end{abstract}

KEY WORDS: Oyster · Crassostrea virginica $\cdot$ Particle selection · Pseudofeces · Selective ingestion · Pseudo-nitzschia multiseries $\cdot$ Domoic acid

\section{INTRODUCTION}

Domoic acid (DA), a competitor for glutamic acid receptors in neuronal cells, has been linked to amnesic shellfish poisoning in humans (Wright et al. 1989) and marine animal intoxication outbreaks (e.g. Scholin et al. 2000) in several regions worldwide (reviewed in Hallegraeff 2003). This toxin, initially found in macroalgae (Daigo 1959), is also produced by diatoms, including several species of the genus Pseudo-nitzschia (reviewed by Trainer et al. 2008). Although suspension-feeding bivalve molluscs are the main vector for
DA transfer to humans, toxin levels in oysters are often very low, even when DA concentrations exceeding the $20 \mathrm{\mu g} \mathrm{g}^{-1}$ regulatory level are present in other cooccurring bivalve species (reviewed by Mafra et al. 2009, this Theme Section).

Since DA uptake by bivalves depends on their capture and ingestion of toxic cells, regulation of the suspension-feeding process can noticeably increase or reduce the amount of toxin available for tissue incorporation. In previous laboratory experiments (Mafra et al. 2009), oysters exhibited a relatively low clearance rate $(\mathrm{CR})$ when exposed to unialgal suspensions of 
either toxic or non-toxic Pseudo-nitzschia multiseries cells, but CR was restored when P. multiseries was combined with an alternative, nutritious food source. As other non-toxic phytoplankton species can be present in the water column during Pseudo-nitzschia spp. blooms, sometimes representing an equivalent or higher algal biomass (e.g. Fehling et al. 2006, Mafra et al. 2006, Spatharis et al. 2007), the low levels of DA commonly found in oysters could also be the result of an effective mechanism of particle selection. Pre-ingestive selection may occur on the gills and/or labial palps of bivalves (Ward et al. 1994, 1998a) and be affected by seston concentration (Barillé et al. 1993), particle morphology and size (Ward et al. 1998b), particle quality (i.e. organic vs. inorganic; Newell \& Jordan 1983, Bayne et al. 1993, Cognie et al. 2003, Beninger et al. 2004) and other characteristics related to the organic content and/or coating of the cells, such as nutritional value (Ward et al. 1997), stickiness (Waite et al. 1995), surface charge (Hernroth et al. 2000) and secreted ectocrines (Ward \& Targett 1989).

On the labial palps of bivalves, nutritious organic particles are typically transported to the mouth for ingestion, while undesirable components are rejected as pseudofeces, which provides a mechanism for enrichment of the food supply (Ward \& Shumway 2004). In oysters, which are characterized by complex, heterorhabdic (i.e. differentiation of ordinary and principal filaments), pseudo-lamellibranch gills capable of bidirectional particle transport, the particle-sorting process starts earlier on the gills. As a result, oysters can selectively and efficiently ingest a given algal species from a mixed suspension while rejecting others as pseudofeces. Some studies have reported that diatom species are preferentially eliminated as pseudofeces from mixed suspensions with flagellates (e.g. Bougrier et al. 1997). However, diatoms may be an important food item for oysters during seasonal diatom blooms when other microalgae are scarce or a more refractory particle type is present (Decottignies et al. 2007).

The sorting capacity of the gills of oysters is also influenced by particle size and morphology. Using qualitative endoscopic observations, Cognie et al. (2003) showed that diatoms with all dimensional axes $\geq 70 \mu \mathrm{m}$ cannot enter the principal filaments and thus cannot be directed efficiently to the dorsal ciliated tracts (dct) of the gills. Instead, such particles are obligatorily transported on the relatively exposed ventral ciliated grooves (vcg), from where a fraction may be lost in pseudofeces. In this case, particle selection can only be performed by the labial palps. Because Pseudo-nitzschia spp. cells are long, but narrow (ca. $5 \mu \mathrm{m}$ wide), some cells can enter the principal filaments if they reach the gills in a dorsoventral orientation. Therefore, Pseudo-nitzschia spp. cells can be transported to both the ventral and dorsal tracts of the gills, as demonstrated by preliminary, qualitative endoscopic observations of the oyster Crassostrea gigas exposed to $80 \mu \mathrm{m}$ long Pseudo-nitzschia sp. cells (J. E. Ward et al. unpubl. data). Additionally, the cell size of diatoms is highly variable, as it decreases over time due to successive vegetative divisions (Round et al. 1990), and Pseudo-nitzschia spp. of varying cell size, including $P$. multiseries cells as short as $35 \mu \mathrm{m}$, can be found during toxic blooms (Bates et al. 1999, Trainer et al. 2007). Thus, we hypothesize that, in oysters, the selective capacity of both the gills and labial palps limits the ingestion of $P$. multiseries cells, and that rejection is enhanced when oysters are exposed to long P. multiseries cells (up to $169 \mu \mathrm{m}$; Villac 1996).

In this study, a combination of feeding experiments and endoscope-directed in vivo sampling was used to investigate the magnitude and site of pre-ingestive selection on the pallial organs of the eastern oysters Crassostrea virginica that could lead to preferential rejection of toxic Pseudo-nitzschia spp. cells from mixed suspensions. Such a mechanism, combined with reduced CR of C. virginica on Pseudo-nitzschia spp. cells in a unialgal suspension (Mafra et al. 2009) could partially explain the low levels of DA accumulation in this and other oyster species. Feeding selectivity was examined via qualitative and quantitative analysis of pseudofeces produced from mixed suspensions of a $P$. multiseries clone with flagellates and other diatom species, and by determining the contribution of the gills and labial palps to this process. In addition, mixed suspensions containing P. multiseries clones of contrasting size were used to assess the effect of cell size on pre-ingestive selectivity. Post-ingestive mechanisms that could contribute to low accumulation of DA in oysters are the subject of ongoing research.

\section{MATERIALS AND METHODS}

Algal culture. Five toxic Pseudo-nitzschia multiseries clones, CLN-20, CLN-30, CLN-46, CLN-50 and CLNN-21, were kindly provided by S. Bates (Department of Fisheries and Oceans, Moncton, Canada) and grown in batch culture. All clones were cultivated in $1.5 \mathrm{l}$ glass Fernbach flasks with autoclaved, $0.22 \mu \mathrm{m}$ cartridge filtered seawater enriched with $f / 2$ medium (Guillard 1975) at $16^{\circ} \mathrm{C}, 30 \mathrm{ppt}$ salinity, a light intensity of $140 \mu \mathrm{mol}$ quanta $\mathrm{m}^{-2} \mathrm{~s}^{-1}$, and a $14 \mathrm{~h}$ light:10 h dark photoperiod. Five non-toxic algae from the Center for Culture of Marine Phytoplankton (CCMP, West Boothbay Harbor, ME) - the flagellates Rhodomonas lens (CCMP Strain 739), Isochrysis galbana (T-Iso clone, CCMP1324) and Pavlova pinguis (CCMP609), and the diatoms Thalassiosira weissflogii (Actin clone, CCMP 
1336) and Chaetoceros muelleri (CCMP1316) - were also batch-cultured in $\mathrm{f} / 2$ medium, without added silicate for the flagellates. They were kept under the same culture conditions as P. multiseries, except for I. galbana and $P$. pinguis, which were cultured in either $20 \mathrm{l}$, aerated, plastic carboys or in a semi-continuous system (200 l photobioreactors) at $20^{\circ} \mathrm{C}$. Cell density of I. galbana, $P$. pinguis and C. muelleri was determined with a Multisizer 3 particle counter (Beckman-Coulter). Cell density of $R$. lens, T. weissflogii and $P$. multiseries clones was measured with a microscope (Leica Model DMLB 100S). Dilutions for microscopy were made to obtain ca. 400 cells per Palmer-Maloney counting chamber.

Cell size (equivalent spherical diameter, ESD) and volume $\left(\mu^{3}\right)$ of Rhodomonas lens, Isochrysis galbana, Pavlova pinguis and Chaetoceros muelleri were obtained using the particle counter. For both Thalassiosira weissflogii and Pseudo-nitzschia multiseries clones, cell length and width $(\mathrm{n}=30)$ were measured prior to each experiment using a microscope with a coupled Pulnix camera (Model TMC-7DSP) and image analysis software (Image Pro Plus Version 4.5, Media Cybernetics). Only cell length of $P$. multiseries clones is reported in Table 1, as width was similar among clones and over time (4.3 to $5.2 \mu \mathrm{m})$. Cellular volume of T. weissflogii was calculated by assuming a cylindrical shape, and that of $P$. multiseries using the formula described by Hillebrand et al. (1999) and modified by Lundholm et al. (2004) for Pseudo-nitzschia spp.: cell volume $\left(\mu^{3}\right)=\left(0.6 \times L \times W^{2}\right)+\left(0.2 \times L \times W^{2}\right)$, where $L$ and $W$ are maximum length and width in micrometers, respectively.
DA concentration in Pseudo-nitzschia multiseries cultures was determined in triplicate by gently filtering $15 \mathrm{ml}$ aliquots through Whatman GF/F glass microfiber filters $(25 \mathrm{~mm}$ diameter, $0.7 \mu \mathrm{m}$ minimum particle retention) followed by analysis of the fluorenylmethoxycarbonyl (FMOC) derivative in cellular and dissolved fractions by high performance liquid chromatography (HPLC) following the methods of Pocklington et al. (1990). All P. multiseries clones were harvested at the stationary phase of growth, when cultures exhibited the maximum intra-cellular toxicity throughout the growth cycle. Only cellular toxicities are reported in Table 1, as particulate DA is known to be the primary route for toxin accumulation (Novaczek et al. 1991). The clones were predominantly single-celled in the stationary phase, with $<5 \%$ of the cells forming short chains of $\leq 4$ cells, such that chain-formation was not a confounding variable in these experiments. Processing of $P$. multiseries chains by Crassostrea virginica is the subject of future investigation.

Selective feeding experiments. Experiments were conducted at the Marine Research Station, Institute for Marine Biosciences (MRS/IMB), National Research Council of Canada (NRC), Halifax, Nova Scotia. Juvenile eastern oysters Crassostrea virginica (first year cohort, mean shell height $[\mathrm{SH}] \pm$ standard error [SE]: $21.4 \pm 0.3 \mathrm{~mm}$ ), were acquired from growers in Prince Edward Island, Canada, in October 2005 and kept in 10001 insulated tanks containing active upwellers at ca. 1500 oysters per tank, $12^{\circ} \mathrm{C}$ and 30 ppt salinity. Shell height represented the maximum dimension from the umbo to the ventral margin of the shell. Oysters were fed Pavlova pinguis and Isochrysis galbana

Table 1. Characteristics of diets exposed to the eastern oyster Crassostrea virginica in endoscopic observations and feeding rate experiments. Diet composition and cell density, toxicity, cell size and total biomass concentration are presented. CLN and CLNN: Pseudo-nitzschia multiseries (Ps-m) clones; C. muelleri: Chaetoceros muelleri; I. galbana: Isochrysis galbana; R. lens: Rhodomonas lens; nt: non-toxic

\begin{tabular}{|c|c|c|c|c|c|}
\hline Experiment & Diet & Composition (cell density in cells $\mathrm{ml}^{-1}$ ) & $\begin{array}{c}\text { Toxicity } \\
\left(\mathrm{pg} \text { DA cell }{ }^{-1}\right) \\
\text { Ps-m /other spp. }\end{array}$ & $\begin{array}{c}\text { Mean cell } \\
\text { size }(\mu \mathrm{m})\end{array}$ & $\begin{array}{c}\text { Total biomass } \\
\text { concentration } \\
\quad\left(\mathrm{mg} \mathrm{l}^{-1}\right)\end{array}$ \\
\hline Feeding & M1 & CLN-20 (9100) + I. galbana (87 000) & $0.7 / \mathrm{nt}$ & $28^{\mathrm{a}} / 4.5^{\mathrm{b}}$ & 7.4 \\
\hline \multirow{7}{*}{ Mixed diets } & M2 & CLN-46 $(2000)+I$. galbana $(81000)$ & $0.8 / \mathrm{nt}$ & $82^{\mathrm{a}} / 4.5^{\mathrm{b}}$ & 6.2 \\
\hline & M3 & CLN-50 $(1800)+I$. galbana $(70000)$ & $0.7 / \mathrm{nt}$ & $100^{\mathrm{a}} / 4.5^{\mathrm{b}}$ & 6.7 \\
\hline & M4 & CLN-50 (2400) + R. lens $(9800)$ & $5.9 / \mathrm{nt}$ & $68^{\mathrm{a}} / 7.6^{\mathrm{b}}$ & 5.8 \\
\hline & M5 & CLN-50 (2800) + C. muelleri (34 000) & $5.9 / \mathrm{nt}$ & $68^{\mathrm{a}} / 5.4^{\mathrm{b}}$ & 6.7 \\
\hline & M6 & CLN-50 (2200) + T. weissflogii (3500) & $0.7 / \mathrm{nt}$ & $100^{\mathrm{a}} / 23^{\mathrm{a}}$ & 8.1 \\
\hline & M7 & CLN-46 (4200) + CLN-20 (11300) & $1.2 / 0.6$ & $82^{\mathrm{a}} / 28^{\mathrm{a}}$ & 11.1 \\
\hline & M8 & CLN-50 (1300) + CLN-20 (7300) & $0.5 / 0.4$ & $90^{\mathrm{a}} / 25^{\mathrm{a}}$ & 5.7 \\
\hline \multirow{3}{*}{$\begin{array}{l}\text { Video- } \\
\text { endoscopy }\end{array}$} & E1 & CLNN-21 (2000) + CLN-30 (7000) + I. galbana (40 000) & $0.2 / 0.03 / \mathrm{nt}$ & $99^{\mathrm{a}} / 35^{\mathrm{a}} / 4.5^{\mathrm{b}}$ & 10.8 \\
\hline & $\mathrm{E} 2$ & CLN-46 $(3700)+R$. lens $(12000)$ & $0.05 / \mathrm{nt}$ & $46^{\mathrm{a}} / 7.6^{\mathrm{b}}$ & 6.8 \\
\hline & E3 & CLN-46 (1400) + T. weissflogii $(1500)+I$. galbana $(40000)$ & $0.07 / \mathrm{nt} / \mathrm{nt}$ & $69^{\mathrm{a}} / 23^{\mathrm{a}} / 4.5^{\mathrm{b}}$ & 4.6 \\
\hline
\end{tabular}


at a total cell density equivalent to $30000 \mathrm{I}$. galbana cells ml ${ }^{-1}$ and acclimated to the experimental diet ca. $18 \mathrm{~h}$ before each trial. After being used in the selectivity experiments, oysters were stored frozen and then oven-dried at $80^{\circ} \mathrm{C}$ for $24 \mathrm{~h}$ to obtain the dry weight (DW) of soft tissue.

Clearance rate $(\mathrm{CR}$, i.e. the volume of water cleared of particles per unit time, in $\mathrm{ml} \mathrm{min}^{-1}$ ) of oysters was measured in five $400 \mathrm{ml}$ acrylic chambers (6 to 8 oysters per chamber), plus 1 chamber without oysters as a control for phytoplankton settlement. Mixing of the suspension was achieved with a motor-driven magnetic stirrer held on the top of the chamber, which prevented disturbance and re-suspension of oyster biodeposits. The experimental diet (Table 1) was gravity-fed to the chambers from a common $60 \mathrm{l}$ header tank, and a peristaltic pump re-circulated the pooled outflow water from the chambers back to the header tank. Following a flow-through acclimation period, flow was interrupted and samples were taken from each chamber before and after a period that allowed oysters to deplete 15 to $30 \%$ of the cells in suspension.

Pseudofeces production rate ( $\mathrm{Pf}$, i.e. number of cells rejected as pseudofeces per unit time, in cells $\mathrm{min}^{-1}$ ) was measured in a similar experimental system, as described in Mafra et al. (2009). CR, filtration and ingestion rates (FR and IR, i.e. number of cells filtered and ingested per unit time; in cells $\mathrm{min}^{-1}$ ) were calculated from the following equations:

$$
\begin{gathered}
\text { CR }\left(\mathrm{ml} \mathrm{min}^{-1}\right)=\left[\left(\log _{\mathrm{e}} C_{\mathrm{i}}-\log _{\mathrm{e}} C_{\mathrm{f}}\right)-\right. \\
\left.\left(\log _{\mathrm{e}} C C_{\mathrm{i}}-\log _{\mathrm{e}} C C_{\mathrm{f}}\right)\right] \times(\mathrm{V} / t)(\text { Coughlan 1969) } \\
\text { FR }\left(\text { cells min } \mathrm{min}^{-1}\right)=\mathrm{CR} \times \text { geomean }\left(C_{\mathrm{i}} C_{\mathrm{f}}\right) \\
\text { IR }\left(\text { cells } \mathrm{min}^{-1}\right)=\mathrm{FR}-\mathrm{Pf}
\end{gathered}
$$

where $C_{\mathrm{i}}$ and $C_{\mathrm{f}}$ are initial and final particle concentrations (cells $\mathrm{ml}^{-1}$ ), $C C_{\mathrm{i}}$ and $C C_{\mathrm{f}}$ are the initial and final particle concentrations in the control chamber, $\mathrm{V}$ is the volume of the chamber (in $\mathrm{ml}$ ) corrected for the volume occupied by the oysters, and $t$ is the incubation time (in min). The geometric means of $C_{\mathrm{i}}$ and $C_{\mathrm{f}}$ were used in the calculation of FR. All measured feeding rates (CR, FR, IR and Pf) were weight-standardized following the general allometric equation for suspension-feeding bivalves as reviewed by Bayne \& Newell (1983):

$$
\mathrm{FdR}_{\text {std }}=\left(W_{\text {avg }} / W_{\exp }\right)^{0.616} \times \mathrm{FdR}_{\exp }
$$

where $F d R_{\text {std }}$ is the weight-standardized feeding rate, $W_{\text {avg }}$ is the soft tissue DW of an average oyster $(0.02 \mathrm{~g}$ in our experiments), $\mathrm{FdR}_{\exp }$ and $W_{\exp }$ are the experimental (i.e. measured) FR and soft tissue DW (in g), respectively.

To investigate selective ingestion/rejection of Pseudonitzschia multiseries cells, clones varying in cell size were tested in mixed suspensions with a second spe- cies, either a flagellate (Diets M1 to M4) or another diatom species (Diets M5 and M6; Table 1). All cellular dimensions (length, width, height) of the species used were $>4.3 \mu \mathrm{m}$, which allows a minimum of ca. 80 to $87 \%$ retention by the oyster gill (Riisgård 1988, Ward \& Shumway 2004). Prior to every trial, cellular volume was calculated for both algal species and the suspension was prepared by adding equivalent cellular volumes of each alga to the 601 header tank. Suspensions were monitored over time to ensure an approximate 50:50 volume ratio of both species throughout the trial, and total concentrations were sufficiently high $\left(\geq 4.2 \mathrm{mg} \mathrm{DW}^{-1}\right.$ ) to assure that pseudofeces were produced. Because $P$. multiseries cells are long but narrow (width $=4.3$ to $5.2 \mu \mathrm{m}$ ), differential retention by the gills was investigated in mixed suspensions with a flagellate or other diatom of a different cell size. For each mixed suspension, CR measurements were taken from a different group of oysters over an interval that was adjusted to limit cell depletion to only 15 to $30 \%$ (ranging from 14 to 19 min for Diets M3, M4 and M5, to 35 to 70 min for M1, M2 and M6). Reduced retention of $P$. multiseries cells by the gills $\left(\mathrm{H}_{1}\right.$; Table 2$)$ is thus verified if the $\mathrm{CR}$ for $P$. multiseries is significantly lower than that for the second alga within a mixed suspension (paired $t$-test; $\alpha=0.05$ ). Pseudofeces production was also measured for each component of the binary diets and used to calculate the IR from Eq. (3). Finally, FR (Eq. 2) was expressed in terms of total cell volume and then partitioned into IR and Pf. The proportion $(p)$ of each algal clone rejected in pseudofeces was compared within each diet, and the hypothesis of selective rejection of $P$. multiseries cells was assessed by $t$-test $(\alpha=0.05)$, following an arcsine transformation.

In addition, cell-volume-based ratios of Pseudonitzschia multiseries to a second species were calculated for the suspension and pseudofeces. A greater ratio in pseudofeces than that offered in the suspension, as revealed by 1 -tailed $t$-test $(\alpha=0.05)$, confirms preferential rejection of $P$. multiseries cells by oysters, as a result of selective filtration and/or rejection $\left(\mathrm{H}_{2 i}\right.$ Table 2).

Two additional suspensions (Diets M7 and M8; Table 1) were prepared by mixing 2 Pseudo-nitzschia multiseries clones with similar toxicity but different cell sizes. They were used to test the effect of $P$. multiseries size alone on selective feeding of oysters. Feeding trials were conducted as before, and ratios of large clone to small clone were calculated in the suspension and pseudofeces. Therefore, if the ratio in pseudofeces differs significantly from that in the offered suspension (2-tailed $t$-test; $\alpha=0.05)$, cell size can be considered as a factor affecting particle selectivity $\left(\mathrm{H}_{2.1}\right.$; Table 2$)$. 
Table 2. Crassostrea virginica. Possible pre-ingestive feeding mechanisms resulting in reduced filtration and/or ingestion of Pseudo-nitzschia multiseries cells, and hypotheses tested in each experiment. dct: dorsal ciliated tracts; EI: electivity index; $\mathrm{CR}_{P s-m}$ : clearance rate of oysters on Pseudo-nitzschia multiseries $(P s-m)$ cells; $\mathrm{CR}_{2 \text { nd sp. }}$ : clearance rate of oysters on a second species in mixed suspension with PS-m; PF: pseudofeces; Susp: suspension; vcg: ventral ciliated grooves

\begin{tabular}{|c|c|c|c|}
\hline $\begin{array}{l}\text { Feeding } \\
\text { process }\end{array}$ & $\begin{array}{l}\text { Avoidance } \\
\text { mechanism }\end{array}$ & $\begin{array}{l}\text { Diets tested } \\
\text { (experiment) }\end{array}$ & Underlying hypotheses \\
\hline $\begin{array}{l}\text { Filtration } \\
\text { by the gills }\end{array}$ & $\begin{array}{l}\text { 1. Reduced retention } \\
\text { of narrow PS- } m \text { cells } \\
\text { on the gills }\end{array}$ & $\begin{array}{l}\text { M1 to M6 } \\
\text { (feeding) }\end{array}$ & $\begin{array}{l}\mathrm{H}_{0} \text { (no reduction): } \mathrm{CR}_{\text {Ps-m }} \geq \mathrm{CR}_{2 \text { nd sp. }} \\
\mathrm{H}_{1} \text { (reduced retention): } \mathrm{CR}_{\text {Ps-m }}<\mathrm{CR}_{2 \text { nd sp. }}\end{array}$ \\
\hline \multirow[t]{4}{*}{ Ingestion } & $\begin{array}{l}\text { 2. Selective rejection } \\
\text { of } P S-m \text { cells in PF }\end{array}$ & $\begin{array}{l}\text { M1 to M6 } \\
\text { (feeding) }\end{array}$ & $\begin{array}{l}\mathrm{H}_{0} \text { (no selection): ratio }\left[P_{S}-m / 2 \mathrm{nd} \mathrm{sp} .\right]_{\mathrm{PF}}=\text { ratio }[P S-m / 2 \mathrm{nd} \mathrm{sp} .]_{\text {Susp }} \\
\mathrm{H}_{2} \text { (selective rejection): ratio }\left[P S-m / 2^{\text {nd }} \mathrm{sp} .\right]_{\mathrm{PF}}>\text { ratio }\left[P S-m / 2^{\text {nd }} \mathrm{sp} .\right]_{\text {Susp }}\end{array}$ \\
\hline & $\begin{array}{l}2.1 \text { Selective rejection } \\
\text { of large cells in PF }\end{array}$ & $\begin{array}{l}\text { M7 and M8 } \\
\text { (feeding) }\end{array}$ & $\begin{array}{l}\mathrm{H}_{0} \text { (no selection): ratio }[\text { large/small cell }]_{\mathrm{Pf}}=\text { ratio }[\text { large/small cell }]_{\text {Susp }} \\
\mathrm{H}_{2.1} \text { (size selection): ratio }[\text { large/small cell }]_{\mathrm{PF}} \neq \text { ratio }[\text { large/small cell }]_{\text {Susp }}\end{array}$ \\
\hline & $\begin{array}{l}\text { 2.2 Particle sorting } \\
\text { on the gills }\end{array}$ & $\begin{array}{c}\text { E1 to E3 } \\
\text { (endoscopy) }\end{array}$ & $\begin{array}{l}\mathrm{H}_{0} \text { (no sorting): EI in the dct }=\mathrm{EI} \text { in the vcg } \\
\mathrm{H}_{2.2} \text { (sorting on the gills): } \mathrm{EI} \text { in the dct } \neq \mathrm{EI} \text { in the vcg }\end{array}$ \\
\hline & $\begin{array}{l}\text { 2.3 Particle sorting } \\
\text { on the labial palps }\end{array}$ & $\begin{array}{c}\text { E1 to E3 } \\
\text { (endoscopy) }\end{array}$ & $\begin{array}{l}\mathrm{H}_{0} \text { (no sorting): } \mathrm{EI} \text { in pseudofeces }=\mathrm{EI} \text { in the } \mathrm{vcg} \\
\mathrm{H}_{2.3} \text { (sorting on the palps): } \mathrm{EI} \text { in pseudofeces } \neq \mathrm{EI} \text { in the vcg }\end{array}$ \\
\hline
\end{tabular}

Because all Pseudo-nitzschia multiseries clones were harvested in the stationary phase and mixed with another species harvested at the exponential phase, an additional experiment was performed to compare the relative rejection of exponential versus stationary $P$. multiseries cells. CLN-20 cells were harvested after 11 and $41 \mathrm{~d}$ of culture, representing mid-exponential and mid-stationary phases, respectively. Oysters were fed similar cell densities of unialgal CLN-20 diets at both growth phases. CR was measured (see Mafra et al. 2009), and pseudofeces were collected to quantify Pf. The proportion of cells rejected as pseudofeces was calculated in both treatments, and the hypothesis that $P$. multiseries cells in exponential and stationary phases are differentially rejected was tested by a $t$-test ( $\alpha=0.05$ ), following arcsine transformation of the proportions.

Video-endoscopic observations. The sites on the pallial feeding organs where selection of Pseudo-nitzschia multiseries cells could potentially take place were investigated in vivo by means of video-endoscopic techniques. Adult Crassostrea virginica (mean $\mathrm{SH} \pm \mathrm{SE}$ : $116 \pm 2 \mathrm{~mm}$ ) were acquired from AquaDelights Seafoods, NS, Canada, and kept in the laboratory under the same conditions as described for juveniles. Two weeks before the experiment, oysters were prepared by carefully trimming the antero-ventral, outer edge of the shell with an electric saw to allow insertion and prevent breakage of the optical insertion tube of the endoscope (Bricelj et al. 1998). Experiments followed methods described in Ward et al. (1991), using an endoscope mounted on a micromanipulator and attached to a colour video camera with an optical-zoom adapter.

Oysters were acclimated to the experimental temperature $\left(18\right.$ to $\left.20^{\circ} \mathrm{C}\right)$ for $2 \mathrm{wk}$ and then transferred to 11 containers. They were fed a diet of 40000 Isochrysis galbana cells $\mathrm{ml}^{-1}$ for $30 \mathrm{~min}$, a sufficient time to ascertain that they had opened their valves and were feeding normally. After this acclimation period, different mixed diets (Table 1) were offered in a flow-through system with a peristaltic pump at $160 \mathrm{ml} \mathrm{min}^{-1}$ for ca. $2 \mathrm{~h}$. The first diet was composed of 2 Pseudonitzschia multiseries clones differing in cell size (Diet E1), the second of a $P$. multiseries clone mixed with the flagellate Rhodomonas lens (Diet E2), and the third diet was composed of a $P$. multiseries clone mixed with an equivalent cell volume of the diatom Thalassiosira weissflogii (Diet E3). In order to stimulate oyster feeding, 40000 I. galbana cells $\mathrm{ml}^{-1}$ were added to Diets E1 and E3 only, as preliminary observations indicated that overall feeding activity was reduced in the presence of a suspension consisting exclusively of diatoms. Duplicate samples of the processed particles were collected from the dorsal ciliated tracts (dct) and ventral ciliated grooves (vcg) with a micropipette connected to a micro-peristaltic pump at a suction rate of $0.55 \mathrm{ml}$ $\mathrm{min}^{-1}$ for ca. $5 \mathrm{~min}$. The material in suspension was sampled every 5 to $10 \mathrm{~min}$ to obtain a time-integrated sample. Duplicate samples of pseudofeces, when available, were also recovered after rejection by the labial palps using a pipette. Electivity indices (EI), based on cell volume, were calculated for pseudofeces, dct and vcg samples using the formula of Jacobs (1974), modified by Ward et al. (1998b):

$$
\mathrm{EI}=\frac{r-p}{(r+p)-(2 r p)}
$$

where $r$ is the proportion of 'Alga B' in the post-capture samples (dct, vcg, pseudofeces), and $p$ is the proportion of the same cells in suspension (food supply). A positive EI indicates enrichment of 'Alga B' in the 
sample, whereas a negative EI indicates enrichment of 'Alga $\mathrm{A}^{\prime}$, the first component of the binary mixed diet.

Isochrysis galbana, offered exclusively to stimulate feeding, was not taken into account for EI calculation. Particle selection on the gills $\left(\mathrm{H}_{2.2}\right.$ i Table 2$)$ is consequently confirmed if EI in the dct is statistically different from that in the vcg. Similarly, if EI of pseudofeces and vcg samples differ significantly, then further particle selection takes place on the labial palps $\left(\mathrm{H}_{2.3}\right.$; Table 2). EI was expressed as an average of 3 to 8 oysters, and the values were compared by 1 -way repeatedmeasures analysis of variance (ANOVAR; $\alpha=0.05$ ).

After the experiment, the gills of 5 oysters were removed and left in filtered seawater at $4^{\circ} \mathrm{C}$ for $2 \mathrm{~h}$. Gills were then observed under a Wild Heerbrugg stereoscope (Model M5-48357) and 5 to 12 principal filament apertures (pfa) were measured from the 2 central demibranchs of each oyster. The pfa is defined as the space between adjacent plicae, which allows access to the principal filament (see Fig. 5). Measurements were taken at $32 \times$ magnification using a coupled camera and image analysis software as described pre- viously for algal measurements. Since the aperture tends to be wider toward the ventral region, each pfa width was expressed as a mean of 7 to 12 measurements taken along the filament. In addition, comparative in vivo measurements were taken from the video images recorded during sampling. In this case, the ordinary filament width, a fairly constant dimension throughout the oyster gills, was measured from dissected oysters and used as a reference to calibrate the video images.

\section{RESULTS}

Oysters cleared Pseudo-nitzschia multiseries cells (i.e. removed from suspension by retaining on the gills) at comparable or higher rates than flagellates and other diatom species offered in mixed, binary suspensions (Fig. 1). The hypothesis that oysters could remove the narrow $P$. multiseries cells from suspension with lower efficiency than other species mixed in a binary $\operatorname{diet}\left(\mathrm{H}_{1}\right.$; Table 2$)$ was thus rejected. Surprisingly, when

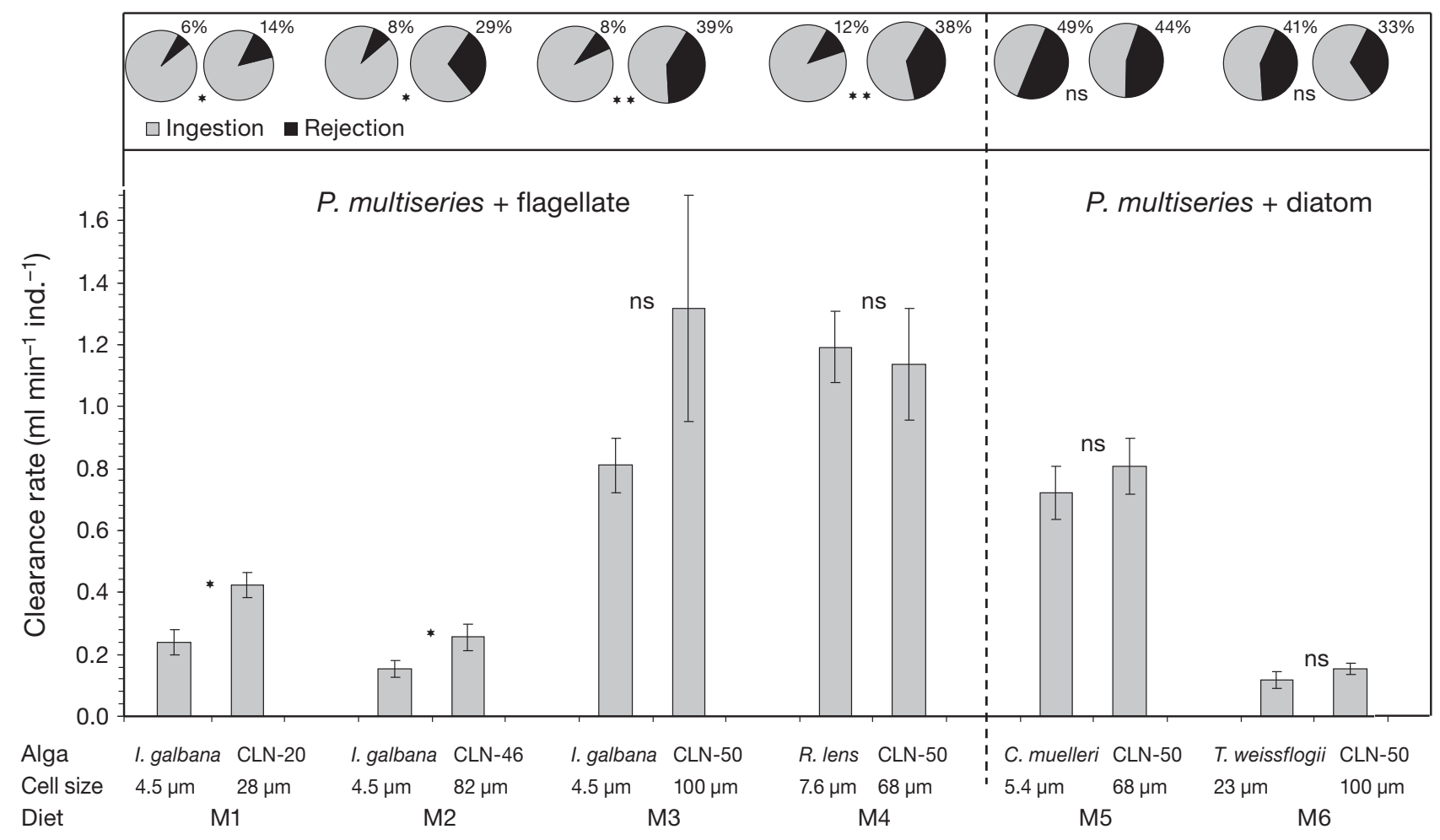

Fig. 1. Crassostrea virginica juveniles (mean shell height \pm SE: $21.4 \pm 0.3 \mathrm{~mm}$ ). Clearance rate (mean $\pm \mathrm{SE}, \mathrm{n}=5 \mathrm{chambers}, 8$ to 12 oysters per chamber) of juvenile oysters fed Pseudo-nitzschia multiseries clones (0.7 to $0.8 \mathrm{pg}$ domoic acid [DA] cell ${ }^{-1}$ ) in various mixed suspensions. Each binary diet was composed of equivalent cell volumes of 2 algae, with cell sizes (length for $P$. multiseries and Thalassiosira weissflogii, and equivalent spherical diameter for Isochrysis galbana, Rhodomonas lens, Chaetoceros muelleri) shown in the graph. Clearance rates for each pair of algae were statistically compared within every diet and results are shown above bars. Pie charts indicate the percentage of filtered cells that were rejected as pseudofeces (in black) in each diet, with statistical results shown between the pairs of charts. ns: non-significant difference; ${ }^{*} p<0.05,{ }^{* *} p<0.01$ 
3 different $P$. multiseries clones, ranging from 28 to $100 \mu \mathrm{m}$ in cell length and 4.6 to $5.0 \mu \mathrm{m}$ in cell width, were mixed with the small and nearly spherical flagellate Isochrysis galbana $(\mathrm{ESD}=4.5 \mu \mathrm{m})$ in Diets $\mathrm{M} 1$ to M3, CR of the latter was significantly lower than that of the $P$. multiseries clone in 2 out of 3 diets tested (M1 and $\mathrm{M} 2, \mathrm{p}=0.02$ and 0.04 , respectively), indicating a lower retention efficiency of $I$. galbana cells by oyster gills. In the third diet (M3), clearance of I. galbana was also lower than that of $P$. multiseries, but because of the high variability of the data the difference was not statistically significant $(p=0.12)$. Differential retention efficiency, as reflected in CR values, was not observed in Diets M4 to M6, in which P. multiseries clone CLN50 was mixed with Rhodomonas lens, Chaetoceros muelleri, or Thalassiosira weissflogii, species with a cell size greater than that of $I$. galbana $(\mathrm{p}=0.78$, 0.22 and 0.58 , respectively). Additionally, there was no relationship between $\mathrm{CR}$ and cell length of $P$. multiseries.

After retention on the gills, particles were either ingested or rejected in pseudofeces. In mixed suspensions, the percentage of particles that were rejected by the oysters varied as a function of particle size and algal species. When mixed with a flagellate (Diets M1 to M4), 14 to $39 \%$ of the filtered Pseudo-nitzschia multiseries cells were rejected as pseudofeces prior to ingestion (Fig. 1), with the greatest percent rejection for the larger clones, CLN-46 in Diet M2 and CLN-50 in Diets M3 and M4. In contrast, rejection of the flagellates Isochrysis galbana (4.5 $\mathrm{mm}$ ESD) and Rhodomonas lens (7.6 $\mu \mathrm{m}$ ESD) from the same suspensions was consistently low, ranging from only 6 to $12 \%$ of the filtered cells (Fig. 1). Percent rejection of $P$. multiseries cells was significantly higher than that of the flagellates in all diets ( $p=0.004$ to 0.037 ). However, when $P$. multiseries was offered in suspension with the smaller diatoms Chaetoceros muelleri (5.4 $\mu \mathrm{m}$ ESD; Diet M5) and Thalassiosira weissflogii (23 $\mu \mathrm{m}_{\text {; }}$ Diet M6), both components of the binary diets were rejected in similar proportions, regardless of cell size and species ( $\mathrm{p}=$ 0.75 and 0.10 , respectively).

Due to both differential retention on the gills and rejection in the pseudofeces, the ratio of Pseudonitzschia multiseries to Isochrysis galbana, expressed in terms of cell volume (Fig. 2; Diets M1 to M3) increased substantially from ca. 1 in the mixed suspension to $3.6,4.8$ and 7.3 in pseudofeces $(p=0.0002$,

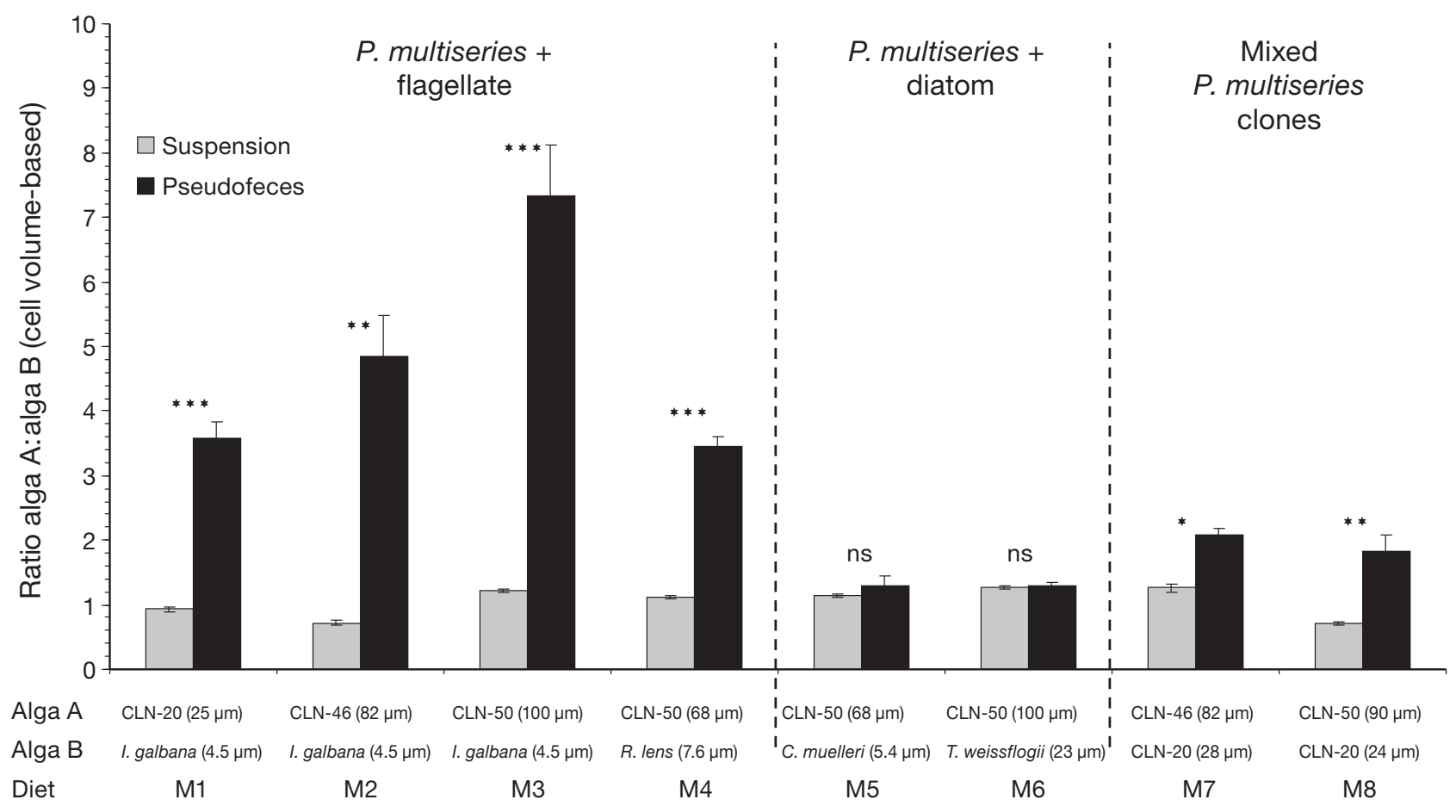

Fig. 2. Crassostrea virginica juveniles (mean shell height \pm SE: $21.4 \pm 0.3 \mathrm{~mm}$ ). Ratio of 2 algae (Alga A:Alga B) in the mixed suspension and in pseudofeces produced by oysters (mean $\pm \mathrm{SE} ; \mathrm{n}=5$ chambers, 6 to 9 oysters per chamber). Oysters were offered various Pseudo-nitzschia multiseries clones in a mixed diet with Isochrysis galbana, Rhodomonas lens, Chaetoceros muelleri, Thalassiosira weissflogii, or another P. multiseries clone of contrasting cell length. Each binary diet was composed of equivalent cell volumes of 2 algae (cell size as defined in Fig. 1 shown in parentheses). Statistical results of within-diet comparisons are shown above bars. ns: non-significant difference; ${ }^{*} \mathrm{p}<0.05,{ }^{* *} \mathrm{p}<0.01,{ }^{* * *} \mathrm{p}<0.001$ 
0.001 and 0.0005 , respectively). In addition, the ratio of P. multiseries to Rhodomonas lens increased significantly from 1.1 in suspension to 3.5 in pseudofeces (Diet M4; p = 0.009), which can only be explained by selective rejection, as the 2 algal species were removed from the mixed suspension at comparable rates. In contrast, no selectivity was observed when oysters were offered CLN-50 in mixed suspensions with the smaller diatom species Chaetoceros muelleri (Diet M5; p = 0.17) and Thalassiosira weissflogii (Diet M6; $\mathrm{p}=0.29$ ). Overall, the hypothesis of preferential rejection of $P$. multiseries cells in pseudofeces $\left(\mathrm{H}_{2}\right.$; Table 2) was only confirmed in diets where P. multiseries was mixed with a flagellate (Figs. 1 \& 2).

When a large Pseudo-nitzschia multiseries clone was combined with the small clone CLN-20 (Diets M7 and M8; Fig. 2), oysters preferentially rejected the larger cells. The ratio of large to small $P$. multiseries cells increased to a lesser degree compared to the diets containing flagellates, from 1.2 in the suspension to 2.1 in pseudofeces for Diet M7 and from 0.7 to 1.8 for Diet M8 (Fig. 2). The differences, however, were statistically significant ( $p=0.014$ and 0.004 , respectively), confirming the hypothesis that cell size affects the selective rejection of $P$. multiseries cells by the oysters $\left(\mathrm{H}_{2.1}\right.$; Table 2).

Oysters removed comparable amounts of Pseudo-nitzschia multiseries cells in exponential and stationary phases from unialgal suspensions, as indicated by the similar FR (Fig. 3). However, because a greater number of cells in the exponential phase was rejected in pseudofeces, the proportion of cells that were actually ingested by the oysters was lower for cultures in exponential than for those in stationary phases $(p=0.027)$.

The video-endoscopy experiments allowed sampling of particles transported on the ventral and dorsal gill tracts, which further elucidated the site of particle selection. Adult oysters (mean pfa width \pm SE: $68.2 \pm 0.6 \mu \mathrm{m})$, exhibited negative EI values in the vcg when fed a mixed diet containing Pseudo-nitzschia multiseries clones of contrasting cell length, indicating considerable enrichment in larger cells (CLNN-21, 'Alga A' = $99 \mu \mathrm{m}$ ) relative to the suspension (Diet E1; Fig. 4). As CLNN-21 cells were preferentially directed to the ventral groove relative to the smaller cells of clone CLN-30 ('Alga B' = $35 \mu \mathrm{m}$ ), the dct were enriched in small CLN-30 cells, as reflected by positive EI values. The hypo-

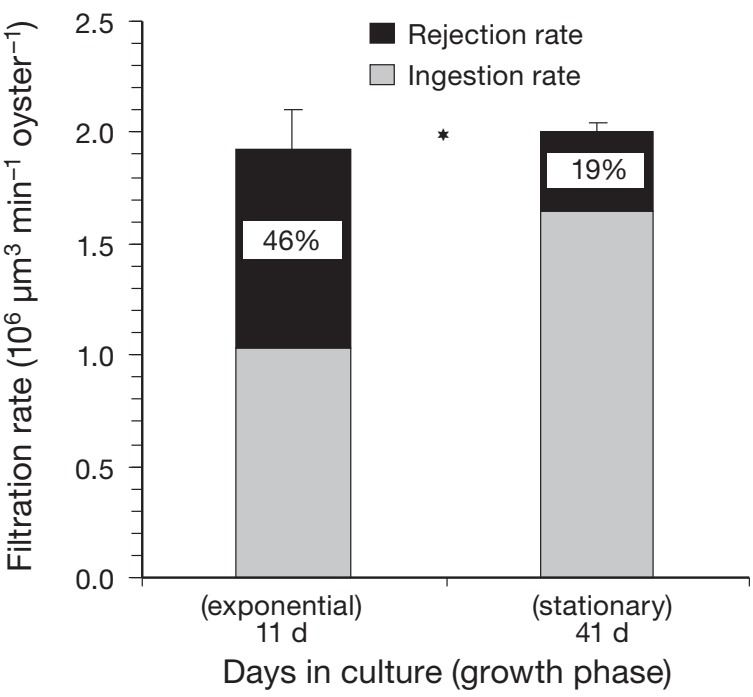

Fig. 3. Crassostrea virginica juveniles (mean shell height \pm SE: $21.4 \pm 0.3 \mathrm{~mm}$ ). Filtration rate (composite bars, mean \pm $\mathrm{SE}$ ) and the relative allocation between ingestion rate and rejection, i.e. pseudofeces production rate $(n=5$ chambers, 8 oysters per chamber) of oysters fed Pseudo-nitzschia multiseries clone CLN-20 at exponential and stationary phases ( 0.07 and 0.6 pg DA cell ${ }^{-1}$, respectively). Star between bars indicates a significant difference in the proportion of cells rejected in pseudofeces $(p<0.05)$. Cell length was equivalent in both growth stages $(25 \mu \mathrm{m})$

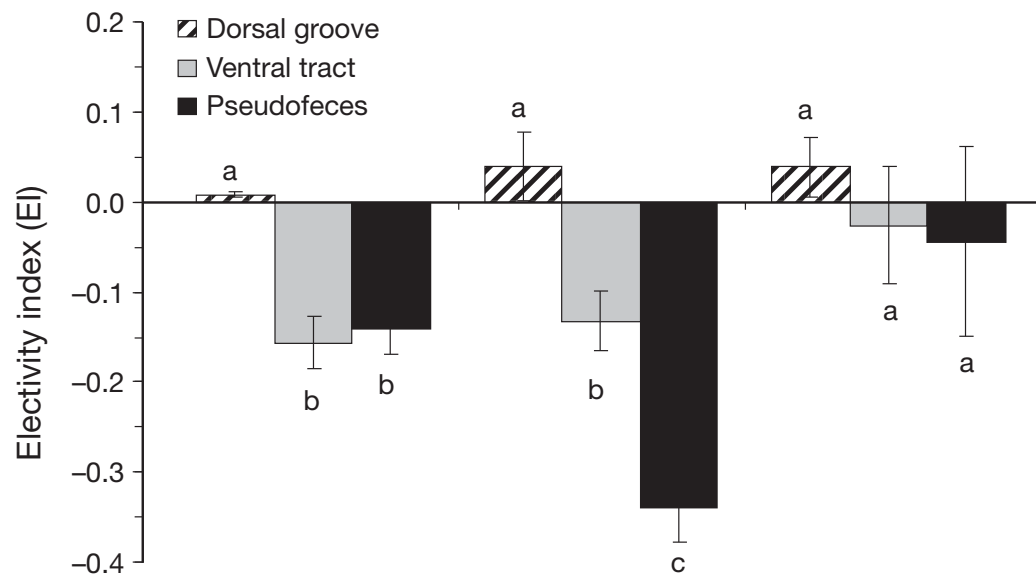

Alga A

Alga $B$

Diet
CLNN-21 $(99 \mu \mathrm{m})$
CLN-30 $(35 \mu \mathrm{m})$

E1
CLN-46 $(46 \mu \mathrm{m})$

R. lens $(7.6 \mu \mathrm{m} \mathrm{ESD})$

E2
CLN-46 $(69 \mu \mathrm{m})$

T. weissflogii $(23 \mu \mathrm{m})$

E3
Fig. 4. Crassostrea virginica adults (mean shell height \pm SE: $116 \pm 2 \mathrm{~mm}$ ). Electivity indices $(E I$, mean $\pm \mathrm{SE}$ ) in the dorsal ciliated tracts, ventral ciliated grooves and in pseudofeces of oysters fed Pseudo-nitzschia multiseries clones in 3 mixed suspensions: Diet E1: CLNN-21 + CLN-30; Diet E2: CLN-46 + Rhodomonas lens; and Diet E3: CLN-46 + Thalassiosira weissflogii. Diets 'E1' and 'E3' were enriched with Isochrysis galbana $\left(40000\right.$ cells ml $\left.{ }^{-1}\right)$ to stimulate feeding. For each diet, a negative EI value indicates enrichment in 'Alga A', with a positive EI indicating enrichment in 'Alga B' at a given sampling site. Different letters indicate statistical difference in EI for each diet $(\alpha=0.05)$. Electivity indices represent the average of 8,6 and 3 oysters in Diets 'E1', 'E2' and 'E3', respectively 

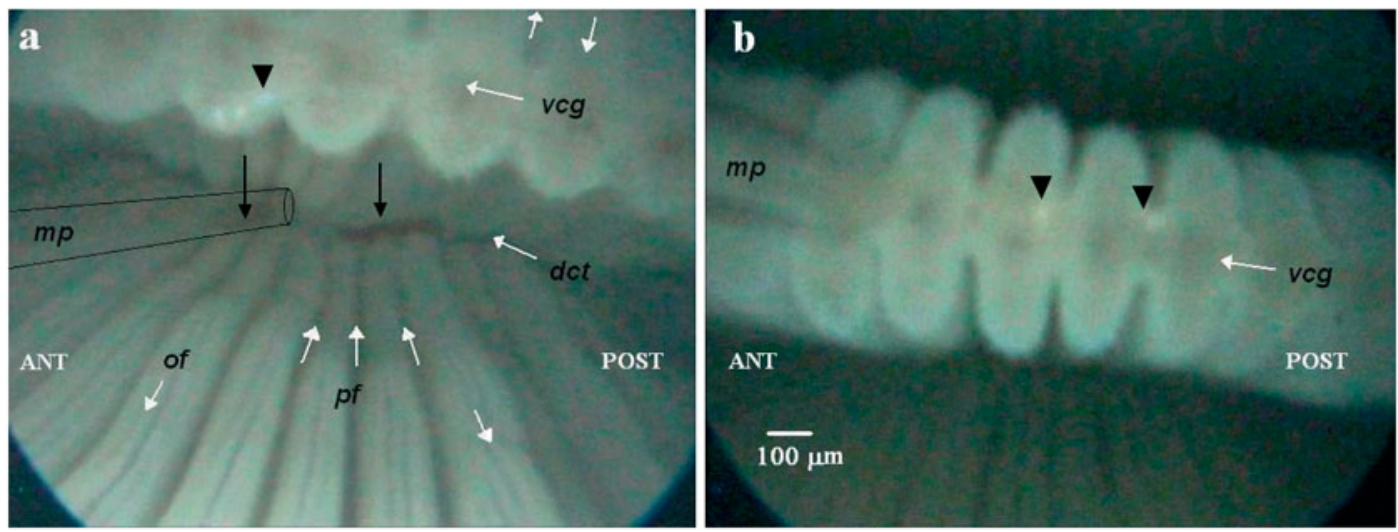

Fig. 5. Crassostrea virginica. Diet E2 (Rhodomonas lens + Pseudo-nitzschia multiseries clone CLN-46); video micrograph taken during endoscope-directed sampling of processed particles on the: (a) dorsal ciliated tract (dct) and (b) ventral ciliated groove $(\mathrm{vcg})$. Note the dominance of reddish particles ( $R$. lens; black arrows) carried on the dct contrasting to the more transparent, bright particles ( $P$. multiseries; black arrowheads) transported on the vcg. White arrows indicate direction of particle transport on the dct, vcg, principal filaments (pf) and on the ordinary filaments (of) that compose the plicae. Samples were taken with a micropipette (mp, outlined in Panel a) connected to a micro-peristaltic pump (see 'Materials and methods'). ANT: anterior; POST: posterior

thesis of particle selection on the gills $\left(\mathrm{H}_{2.2}\right.$; Table 2$)$ was strongly supported by the markedly different EI values between the dct and vcg $(p=0.001)$. In addition, the EI in pseudofeces did not differ from that in the vcg of the gills ( $p=0.99$ ), showing that no further sorting based on particle size took place on the labial palps.

Particle sorting also occurred on the gills of oysters fed the flagellate Rhodomonas lens in a mixed suspension with a relatively small $(45 \mu \mathrm{m})$ Pseudo-nitzschia multiseries clone, CLN-46 (Diet E2; Figs. 4 \& 5). Similarly to the first diet, the negative EI measured in the vcg differed significantly from the positive EI found in the dct $(p=0.018)$, indicating selective rejection of $P$. multiseries on the gills. This time, however, additional rejection of $P$. multiseries occurred on the labial palps, as indicated by the significantly greater negative EI of pseudofeces samples compared to the ventral groove samples $(p=0.021)$. This result shows that both the gills and labial palps can be active sites for particle selection in the oysters Crassostrea virginica. In contrast, no particle selectivity was found on the gills or on the labial palps of oysters fed $P$. multiseries clone CLN$46(69 \mu \mathrm{m})$ in a mixed suspension with another diatom, Thalassiosira weissflogii (Diet E3; Fig. 4).

\section{DISCUSSION}

In a companion study (Mafra et al. 2009), we found that a combination of low CR and increasing pseudofeces production at higher cell densities led to reduced ingestion of Pseudo-nitzschia multiseries from unialgal suspensions by Crassostrea virginica. In the same study, oysters were found to exhibit a higher overall CR when $P$. multiseries clones were offered in a mixed suspension with the flagellate Isochrysis galbana. Since toxic Pseudo-nitzschia spp. blooms in the natural environment are often associated with high abundances of other algal species (Fehling et al. 2006, Mafra et al. 2006, Spatharis et al. 2007), including multiple Pseudonitzschia spp. (Rines et al. 2002, Kaczmarska et al. 2007), this finding suggests that DA intake by oysters could be facilitated in mixed suspensions with a more palatable food source. In the present study, oyster gills were shown to clear $P$. multiseries cells at similar or higher rates than flagellate species in a mixed suspension. However, after capture on the gills, P. multiseries cells were preferentially rejected by both juvenile and adult oysters in pseudofeces, leading to enrichment of the ingested food in flagellates and potentially reducing the DA intake by the shellfish. When P. multiseries clones were mixed in suspension with another diatom species, no selective feeding occurred and both algae were similarly rejected in pseudofeces.

In the present study, differential clearance of cells did not occur when juvenile oysters were fed the relatively long and narrow Pseudo-nitzschia multiseries in mixed suspensions with another relatively large but more spherical diatom species or the flagellate Rhodomonas lens (Diets M4 to M6; Fig. 1). However, when different $P$. multiseries clones, ranging in cell length from 28 to $100 \mu \mathrm{m}$, were mixed in a binary diet with the smaller flagellate Isochrysis galbana $(4.5 \pm 0.6 \mu \mathrm{m}$, mean ESD $\pm \mathrm{SD}$ ), the latter was removed from suspension at a consistently lower rate than $P$. multiseries, irrespective of clone size (Diets M1 to M3; Fig. 1). Since both algal particles theoretically approach the gills at the same velocity, the result suggests that Crassostrea 
virginica gills may have retained I. galbana with lower efficiency than $P$. multiseries cells in the present study. For $C$. virginica, the reported size threshold at which particles are filtered with $100 \%$ efficiency varies somewhat among individual studies, but averaged data suggest that only particles $\geq 5$ to $6 \mu \mathrm{m}$, slightly larger than I. galbana cells, can be fully retained on the gills (Ward \& Shumway 2004). Moreover, exposure to high particle concentrations may reduce bivalve retention efficiency by changing the interfilamentary distance of the gills. For example, Palmer \& Williams (1980) showed that retention efficiency of $C$. virginica for particles $>4.35 \mu \mathrm{m}$ dropped from $100 \%$ at $1.4 \mathrm{mg} \mathrm{DW}$ seston $\mathrm{m}^{-1}$ to $86 \%$ at concentrations as high as $6.5 \mathrm{mg} \mathrm{l}^{-1}$. Because the total biomass concentrations of Diets M1 to M3 ranged from 6.2 to $7.4 \mathrm{mg} \mathrm{l}^{-1}$ in the present study, the lower clearance of $I$. galbana in mixed suspensions with $P$. multiseries is attributed to $<100 \%$ retention efficiency of the former alga. Periodic variations in gill porosity were also observed by Haven \& Morales-Alamo (1970) in C. virginica feeding at high seston concentrations (ca. $10 \mathrm{mg} \mathrm{l}^{-1}$ ), and helped to explain how oysters can vary their $\mathrm{CR}$ while keeping the valves open (Palmer 1980). Variations of the oysters' retention efficiency would not affect filtration of $P$. multiseries cells at high cell densities because of their large size, and this is not expected to be a mechanism contributing to reduce DA intake from toxic cells at bloom densities. In fact, unialgal suspensions of 2 Pseudo-nitzschia species, P. multiseries and P. pseudodelicatissima, at common bloom concentrations (ca. $10^{6}$ cells $\mathrm{l}^{-1}$ ) were filtered by $C$. virginica at rates comparable to 2 other diatoms, Thalassiosira weissflogii and Ditylum brightwellii (Thessen et al. 2002).

Although the presence of a flagellate in mixed suspensions with Pseudo-nitzschia multiseries was shown to increase the overall $\mathrm{CR}$ in Crassostrea virginica (Mafra et al. 2009), some CR values reported in the present study were unexpectedly low, namely for Diets M1 and M2 (Fig. 1). High particle concentrations, such as those used in these diets, may lead to CR reduction in bivalves (Riisgård 2001). This was unlikely the case in the present study, however, as oysters exposed to other mixed suspensions at comparable concentrations (Diets M3 to M4; Table 2) showed much higher CR (Fig. 1). It is also improbable that the lower $C R$ values observed in Diets M1 and M2 were due to artefacts in the measurement of clearance, since the method employed was the same for all diets and precautions to limit recirculation in the chambers by maintaining $\leq 30 \%$ depletion were taken. As Riisgård (2001) pointed out, even when suitable methods are applied, disparity in CR values between different experiments may reflect differences in bivalve condition and/or the influence of environmental factors.
We provide independent evidence from both feeding rate experiments with juvenile oysters and quantitative video-endoscopic observations of particle transport on the gills of adult oysters that the size of Pseudonitzschia multiseries cells is a critical factor influencing oyster pre-ingestive selection. The percentage of $P$. multiseries cells rejected in pseudofeces from mixed suspensions with Isochrysis galbana increased with an increase in cell length from 23 to $100 \mu \mathrm{m}$ (Diets M1 to M4; Fig. 1). In addition, oysters preferentially rejected the larger $P$. multiseries clones CLN-46 (82 $\mu \mathrm{m})$ and CLN-50 $(90 \mu \mathrm{m})$ when offered in mixed suspensions with the smaller (24 to $28 \mu \mathrm{m}$ ) and similarly toxic clone CLN-20 (Diets M7 and M8; Fig. 2). Video-endoscopyassisted sampling confirmed that the selective ability of oyster gills was affected when large cells were filtered. At least a portion of the larger $P$. multiseries cells, likely those not dorsoventrally oriented, was unable to enter the principal filaments, and was thus carried along the ventral grooves of Crassostrea virginica (Diet E1; Fig. 4). This confirms that a single algal species, $P$. multiseries, can be selected by $C$. virginica based exclusively on cell size, as previously demonstrated with polystyrene beads of contrasting diameters (40 and $275 \mu \mathrm{m}$ ) by Tamburry \& Zimmer-Faust (1996). The gills were the only possible site for such selection, as we found no further selectivity on the labial palps (Diet E1; Fig. 4).

The present study also provides quantitative data that support the qualitative video-endoscopy observations made by Cognie et al. (2003) in the Pacific oyster Crassostrea gigas. Using the large, non-toxic pennate diatoms Pleurosigma planctonicum and Rhizosolenia setigera, and the centric diatom Coscinodiscus perforatus, these researchers found that cells with all axes

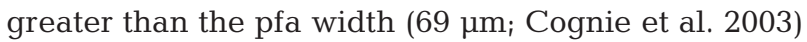
and some cells with 1 axis exceeding this width were unable to enter the principal filaments. Because the pfa width in our study $(68.2 \pm 0.6 \mu \mathrm{m}$, mean $\pm \mathrm{SE})$ was measured from relaxed, dissected gills, this measurement cannot be considered as a fixed threshold. During our video-endoscopic observations, this gap appeared to be variable and even disappeared as oysters stretched and contracted their gills. Our in vivo measurements of the pfa width from actively feeding Crassostrea virginica, however, were on average $66.7 \pm 1.3 \mu \mathrm{m}$, mean $\pm \mathrm{SE}$, very similar to the values we obtained from dissected gills and those reported earlier for C. gigas.

Pseudo-nitzschia spp. cells are noticeably smaller and narrower (ca. $5 \mu \mathrm{m}$ width) than the diatoms used by Cognie et al. (2003), in which the 2 pennate species were characterized by a length of 350 to $700 \mu \mathrm{m}$ and a width of 35 to $40 \mu \mathrm{m}$. In the present study, we used $P$. multiseries clones of contrasting sizes to obtain a mixed suspension of cells either shorter or longer than the pfa 
width, and confirmed that cells with 1 axis longer than this critical size are selectively rejected by oysters. Furthermore, our quantitative measures of feeding selection were obtained for a planktonic, toxic alga of public health relevance. Confirmation that oysters selectively reject high proportions of $P$. multiseries cells $>70 \mu \mathrm{m}$ in length is particularly important, given that at least $92 \%$ of cells in the natural environment exceed this size threshold (Bates et al. 1999), and that Pseudo-nitzschia spp. of highly varying cell size have been associated with shellfish closures during toxic blooms (Trainer et al. 2007). In addition, this finding has major ecological significance as Pseudo-nitzschia spp. are a ubiquitous component of the phytoplankton in coastal waters worldwide (Hasle 2002). Although cell toxicity may be directly related to the size of a given $P$. multiseries clone, we demonstrated that CR inhibition of oysters fed Pseudo-nitzschia spp. cells could not be attributed to DA toxicity (Mafra et al. 2009). Therefore, it is improbable that DA toxicity was the cause of the selective feeding of oysters exposed to $P$. multiseries in the present study. Furthermore, in previous endoscopic observations (L. L. Mafra et al. unpubl. data), larger $P$. multiseries cells $\left(100 \mu \mathrm{m} ; 0.6 \mathrm{pg} \mathrm{DA} \mathrm{cell}{ }^{-1}\right)$ were preferentially rejected by adult $C$. virginica, even when mixed in suspension with a smaller but more toxic clone $\left(24 \mu \mathrm{m} ; 1.1 \mathrm{pg}\right.$ DA cell $\left.{ }^{-1}\right)$.

Results of our study suggest that factors other than cell size are involved in particle selection by the gills and labial palps of Crassostrea virginica. This conclusion is based on the fact that relatively small flagellates and diatoms (4.5 to $28 \mu \mathrm{m}$ ) were differentially rejected in pseudofeces when offered in a mixed suspension with a Pseudo-nitzschia multiseries clone, some of which had cell sizes smaller than the pfa width $(<68 \mu \mathrm{m})$. Similar findings have been reported previously for $C$. gigas when delivered a mixed suspension of 2 qualitatively different particle types of comparable size, e.g. Spartina spp. detrital particles and Rhodomonas lens (Ward et al. 1997) and, more recently, when delivered a mixed suspension of the live diatoms Actinoptychus senarius and artificially cleaned, empty frustules (Beninger et al. 2008a). In the present study, we show conclusively that $C$. virginica was able to sort among algae of similar size from different taxa (i.e. diatoms vs. flagellates). While flagellated cells were mostly ingested (Fig. 1), up to $49 \%$ of the small diatoms (cell size $<68 \mu \mathrm{m}$ ) were rejected in pseudofeces of oysters when offered in mixed suspensions with either Isochrysis galbana or a larger P. multiseries clone. Similarly, in a previous study, the diatom Phaeodactylum tricornutum was preferentially rejected in the pseudofeces of 5 other bivalve species when delivered in a mixed suspension with the dinoflagellate Prorocentrum minimum and the naked flagellate Chroomonas salina (Shumway et al. 1985). Prior studies have suggested that bivalves make use of chemical cues to discriminate among particles (Newell \& Jordan 1983, Shumway et al. 1985, Ward \& Targett 1989). Contact with the extracellular organic envelope, whose composition varies from diatoms to flagellates (Ward \& Targett 1989) and even among diatom species (Volcani 1981), may be a major cue for selection by bivalve pallial organs. Alternatively, substances released from inside the cell or from its organic covering may be recognized by some bivalves, since Crassostrea gigas was able to selectively reject permeable microcapsules enclosing the diatom Nitzschia closterium while preferentially ingesting those containing the green alga Tetraselmis suecica (Espinosa et al. 2007).

Diatoms may contain metabolites that cause inhibitory effects on feeding and fitness parameters of suspension-feeding grazers (Shaw et al. 1995, Ianora et al. 2003). Whether such metabolites affect particle selection in bivalves, however, is not known. When Bougrier et al. (1997) offered 5 diets composed of a combination of 3 to 4 species from different taxa, Crassostrea gigas preferentially rejected in pseudofeces 3 relatively small diatom species (Skeletonema costatum, Chaetoceros calcitrans and Nitzschia closterium) compared with 3 similarly sized flagellate species (Pavlova lutheri, Tetraselmis suecica and I. galbana). In a study on the European oyster Ostrea edulis, Bricelj et al. (1998) reported that, compared to several dinoflagellates, the diatom Thalassiosira weissflogii was mainly transported along the ventral grooves of the gill where material is more likely to be rejected in pseudofeces. The present study shows that Crassostrea virginica were unable to sort between 2 diatom species, when Pseudo-nitzschia multiseries clones were mixed in a suspension with T. weissflogii or Chaetoceros muelleri (Diets M5 and M6; Fig. 2). This contrasts with the ability of C. gigas to preferentially ingest 2 out of 4 benthic diatom species from the Naviculaceae family, ranging in cell length from 22 to $60 \mu \mathrm{m}$ (Cognie et al. 2001).

The present study provides the first evidence that selection of different microalgal species may occur concurrently in 2 distinct pallial organs of a heterorhabdic bivalve. In a mixed suspension with the flagellate Rhodomonas lens, selective rejection of Pseudonitzschia multiseries clone CLN-46 occurred simultaneously on the gills and labial palps of Crassostrea virginica (Diet E2; Figs. 4 \& 5). This dual-site sorting capacity, suggested to be a general ability of heterorhabdic bivalves, has been confirmed in the scallop Pecten maximus (Beninger et al. 2004) and the oyster Crassostrea gigas (Beninger et al. 2008a), which were fed live and artificially cleaned, dead diatoms. However, oysters seem to have a more refined particle 
selection mechanism than scallops. This idea was recently supported by the work of Beninger et al. (2008b), who found that, contrary to the scallop P. maximus (Beninger \& Decottignies 2005), the oyster C. gigas was able to distinguish between live and naturally dead diatoms in a mixed suspension, the latter still covered by a peri-frustular envelope.

The chemical mechanisms involved in particle selection have not been elucidated, but the mapping of mucocytes on the labial palps and gill epithelium of different bivalve species is consistent with the use of mucus during the entire particle handling process (Beninger et al. 1993, 2005, Beninger \& Dufour 1996). Mucocytes of the pallial organs secrete mucus of varying viscosity for different functions (Beninger \& Dufour 1996, Beninger \& St.-Jean 1997, Beninger et al. 2005). Except for the dorsal tracts and principal filaments, transport of particles occurs on relatively exposed sites of the oyster gills in a perpendicular or opposite direction to the prevailing inhalant current (Ward et al. 1994); thus, transport is only possible if particles strongly adhere to the ciliated epithelium by mucus (Beninger et al. 2005). Of all components of bivalve mucus, lectins (Fisher 1992) are the most probable to act as a particle agglutinant. Lectins are glycoproteins of non-immune origin that specifically and reversibly conjugate with sugars (Goldstein et al. 1980), including those covering algal cells (Waite et al. 1995, Cho 2003). A mannose-binding lectin has been shown to act as a feeding receptor for prey recognition by the heterotrophic dinoflagellate Oxyrrhis marina (Wootton et al. 2007), and recent studies suggest that lectins in mucus secreted by the feeding organs of Crassostrea virginica may be involved in particle selection (Espinosa et al. 2008). Affinity for different lectins varies among diatom species (Waite et al. 1995) and between diatoms and dinoflagellates, with the latter binding to a greater variety of lectin types (Cho 2003). Thus, if lectins associated with the feeding structures bind more effectively to certain groups of microalgae, this might explain why $C$. virginica showed no preingestive selection among diatom species, but demonstrated selection between Pseudo-nitzschia multiseries and 2 flagellate species.

Oysters in the present study rejected greater amounts of exponentially growing Pseudo-nitzschia multiseries cells than those in the stationary phase. This finding could be explained by the fact that accumulation of cell-surface carbohydrates is lower in diatoms undergoing faster growth (Waite et al. 1995). Cell stickiness also tends to be lower in the exponential phase, which may influence adhesion between the cells and surfaces of the feeding structures. These factors may help to explain the preferential rejection of cleaned, empty frustules over intact diatom cells by Pecten maximus (Beninger et al. 2004) and Crassostrea gigas (Cognie et al. 2003), and rejection of naturally dead over live cells by $C$. gigas (Beninger et al. 2008b), assuming that the composition of the peri-frustular envelope changes after cell death. Therefore, it is unlikely that the use of $P$. multiseries cells in the stationary phase in our mixed diets caused their preferential rejection over flagellates by the oysters, since cells growing exponentially were rejected to an even greater degree in both unialgal (Fig. 3) and mixed diets (data not shown). Additionally, the similar feeding selectivity found in both juvenile $(21.4 \pm 0.3 \mathrm{~mm}$, mean $\mathrm{SH} \pm \mathrm{SE})$ and adult (116 $\pm 2 \mathrm{~mm}$, mean $\mathrm{SH} \pm \mathrm{SE})$ Crassostrea virginica confirms that the pallial organs were fully developed in the 1 to $1.5 \mathrm{yr}$ old juveniles used in the present study. In fact, after 16 to $22 \mathrm{wk}$ of rearing at 22 to $25^{\circ} \mathrm{C}$, the complete mantle rejection system of C. gigas was functional in juveniles between 10 and $24 \mathrm{~mm}$ in shell height (Beninger \& Cannuel 2006).

In conclusion, the relatively low DA levels found in Crassostrea virginica when exposed to toxic Pseudonitzschia spp. blooms can be explained at least partially by 2 processes: (1) pre-ingestive rejection of $P$. multiseries in mixed suspensions, which is more pronounced for larger cells (present study), and (2) reduced $\mathrm{CR}$ elicited in unialgal suspensions (Mafra et al. 2009). Indeed, 2 wk contamination experiments in the laboratory confirmed that $C$. virginica accumulates much less DA from $P$. multiseries than the mussel Mytilus edulis under the same experimental conditions, and that the difference was much greater when larger cells $(>68 \mu \mathrm{m})$ were offered (L. L. Mafra et al. unpubl. data). In our study, P. multiseries occurred mostly as single cells (>95\%); thus, the role of chain formation by $P$. multiseries on the selective ability of oysters requires further investigation. Nevertheless, we suggest that rejection of this toxic diatom by oysters will be more pronounced during natural blooms, when large cells are growing exponentially and favourable conditions trigger the formation of long, stepped chains. As a result, oysters in contact with multi-specific blooms, dominated by toxic Pseudo-nitzschia spp. and other non-toxic species, may filter a high biomass of phytoplankton without necessarily accumulating the levels of DA predicted from their clearance rates.

Acknowledgements. The authors acknowledge the valuable contribution of C. Ouellette to several aspects of this investigation and the technical assistance by S. MacQuarrie and M. Anderson during the experiments. We thank C. Léger and S. Bates for providing the Pseudo-nitzschia multiseries clones and their toxicity characterization and S. E. Shumway and R. A. Horner for the unpublished data on previous endoscopic observations. We also thank the Conselho Nacional de Desenvolvimento Científico e Tecnológico (CNPq/Brazil) for the PhD scholarship granted to L.L.M. This research was 
funded by the ACOA Atlantic Innovation Fund (AIF) and Canadian Food Inspection Agency, with partial support from the NOAA-ECOHAB Grant NA04NOS4780275 awarded to J. Kraeuter at Rutgers University, NJ. An earlier version of this manuscript was substantially improved thanks to the comments and suggestions made by P. Beninger and 2 other anonymous reviewers. IMB/NRC complies with regulations from the Canadian Council of Animal Care.

\section{LITERATURE CITED}

Barillé L, Prou J, Heral M, Bougrier S (1993) No influence of food quality, but ration-dependent retention efficiencies in the Japanese oyster Crassostrea gigas. J Exp Mar Biol Ecol 171:91-106

Bates SS, Hiltz MF, Léger C (1999) Domoic acid toxicity of large new cells of Pseudo-nitzschia multiseries resulting from sexual reproduction. In: Martin JL, Haya K (eds) Proceedings of the 6th Canadian workshop on harmful marine algae. Can Tech Rep Fish Aquat Sci 2261:21-26

Bayne BL, Newell RC (1983) Physiological energetics of marine molluscs. In: Saleuddin ASM, Wilbur KM (eds) The Mollusca, Vol 4. Academic Press, New York, p 407-515

Bayne BL, Iglesias JIP, Hawkins AJS, Navarro E, Heral M, Deslous-Pauli JM (1993) Feeding behavior of the mussel Mytilus edulis: responses to variations in quantity and organic content of seston. J Mar Biol Assoc UK 73:813-829

Beninger PG, Cannuel R (2006) Acquisition of particle processing capability in the oyster Crassostrea gigas: ontogeny of the mantle pseudofeces rejection tracts. Mar Ecol Prog Ser 325:153-163

Beninger PG, Decottignies P (2005) What makes diatoms attractive for suspensivores? The organic casing and associated organic molecules of Coscinodiscus perforatus are quality cues for the bivalve Pecten maximus. J Plankton Res 27:11-17

Beninger PG, Dufour SC (1996) Mucocyte distribution and relationship to particle transport on the pseudolamellibranch gill of Crassostrea virginica (Bivalvia: Ostreidae). Mar Ecol Prog Ser 137:133-138

Beninger PG, St-Jean SD (1997) The role of mucus in particle processing by suspension-feeding marine bivalves: unifying principles. Mar Biol 129:389-397

Beninger PG, St-Jean SD, Poussart Y, Ward JE (1993) Gill function and mucocyte distribution in Placopecten magellanicus and Mytilus edulis (Mollusca: Bivalvia): the role of mucus in particle transport. Mar Ecol Prog Ser 98:275-282

Beninger PG, Decottignies P, Rincé Y (2004) Localization of qualitative particle selection sites in the heterorhabdic filibranch Pecten maximus (Bivalvia: Pectinidae). Mar Ecol Prog Ser 275:163-173

Beninger PG, Cannuel R, Jaunet S (2005) Particle processing on the gill plicae of the oyster Crassostrea gigas: fine-scale mucocyte distribution and functional correlates. Mar Ecol Prog Ser 295:191-199

Beninger PG, Valdizan A, Decottignies P, Cognie B (2008a) Impact of seston characteristics on qualitative particle selection sites and efficiencies in the pseudolamellibranch bivalve Crassostrea gigas. J Exp Mar Biol Ecol 360:9-14

Beninger PG, Valdizan A, Cognie B, Guiheneuf F, Decottignies $P$ (2008b) Wanted: alive and not dead-functioning diatom status is a quality cue for the suspension-feeder Crassostrea gigas. J Plankton Res 30:689-697

Bougrier S, Hawkins AJS, Héral M (1997) Preingestive selection of different microalgal mixtures in Crassostrea gigas and Mytilus edulis, analysed by flow cytometry. Aqua- culture 150:123-134

Bricelj VM, Ward JE, Cembella AD, MacDonald BA (1998) Application of video-endoscopy to the study of bivalve feeding on toxic dinoflagellates. In: Reguera B, Blanco J, Fernández ML, Wyatt $\mathrm{T}$ (eds) Harmful algae. Xunta de Galicia and IOC of UNESCO Publishers, Vigo, p 453-456

Cho ES (2003) Cluster analysis on the lectin binding patterns of marine microalgae. J Plankton Res 25:309-315

Cognie B, Barillé L, Rincé Y (2001) Selective feeding of the oyster Crassostrea gigas fed on a natural microphytobenthos assemblage. Estuaries 24:126-131

Cognie B, Barillé L, Massé G, Beninger PG (2003) Selection and processing of large suspended algae in the oyster Crassostrea gigas. Mar Ecol Prog Ser 250:145-152

Coughlan J (1969) The estimation of filtering rate from the clearance of suspensions. Mar Biol 2:356-358

Daigo K (1959) Studies on the constituents of Chondria armata. I: detection of the antihelmintical constituents \& II: isolation of an antihelmintical constituent. J Pharm Soc Japan 79:350-356

> Decottignies P, Beninger PG, Rincé Y, Riera P (2007) Trophic interactions between two introduced suspension-feeders, Crepidula fornicata and Crassostrea gigas, are influenced by seasonal effects and qualitative selection capacity. J Exp Mar Biol Ecol 342:231-241

Espinosa EP, Barillé L, Allam B (2007) Use of encapsulated live microalgae to investigate pre-ingestive selection in the oyster Crassostrea gigas. J Exp Mar Biol Ecol 343: $118-126$

Espinosa EP, Perrigault M, Shumway SE, Ward JE, Wikfors G, Allam B (2008) The sweet relationship between microalgae and Crassostrea virginica: implications of carbohydrate and lectin interactions in particle selection in suspension feeding bivalves. Shellfish Res 27:1006-1007

Fehling J, Davidson K, Bolch C, Tett P (2006) Seasonality of Pseudo-nitzschia spp. (Bacillariophyceae) in western Scottish waters. Mar Ecol Prog Ser 323:91-105

Fisher WS (1992) Occurrence of agglutinins in the pallial cavity mucus of oysters. J Exp Mar Biol Ecol 162:1-13

Goldstein IJ, Hughes RC, Monsigny M, Osawa T, Sharon N (1980) What should be called a lectin? Nature 285:66

Guillard RRL (1975) Culture of phytoplankton for feeding marine invertebrates. In: Smith WI, Chanley MH (eds) Culture of marine invertebrates. Plenum, New York, p 29-59

Hallegraeff GM (2003) Harmful algal blooms: a global overview. In: Hallegraeff GM, Anderson DM, Cembella $\mathrm{AD}$ (eds) Manual on harmful marine microalgae-Monographs on oceanographic methodology 11. UNESCO, Paris, p 25-50

Hasle GR (2002) Are most of the domoic acid-producing species of the diatom genus Pseudo-nitzschia cosmopolites? Harmful Algae 1:137-146

> Haven DS, Morales-Alamo R (1970) Filtration of particles from suspension by the American oyster Crassostrea virginica. Biol Bull 139:248-264

Hernroth B, Larsson A, Edebo L (2000) Influence on uptake, distribution and elimination of Salmonella typhimurium in the blue mussel, Mytilus edulis, by the cell surface properties of the bacteria. J Shellfish Res 19:167-174

> Hillebrand H, Dürselen CD, Kirschtel D, Pollingher U, Zohary $\mathrm{T}$ (1999) Biovolume calculation for pelagic and benthic microalgae. J Phycol 35:403-424

Ianora A, Poulet SA, Miralto A (2003) The effects of diatoms on copepod reproduction: a review. Phycologia 42:351-363

> Jacobs J (1974) Quantitative measurement of food selection. Oecologia 14:413-417 
Kaczmarska I, Martin JL, Ehrman JM, LeGresley MM (2007) Pseudo-nitzschia species population dynamics in the Quoddy Region, Bay of Fundy. Harmful Algae 6:861-874

Lundholm N, Hansen PJ, Kotaki Y (2004) Effect of pH on growth and domoic acid production by potentially toxic diatoms of the genera Pseudo-nitzschia and Nitzschia. Mar Ecol Prog Ser 273:1-15

Mafra LL Jr, Fernandes LF, Proença LAO (2006) Harmful algae and toxins in Paranaguá Bay, Brazil: bases for monitoring. Braz J Oceanogr 54:107-121

Mafra LL Jr, Bricelj VM, Ouellette C, Léger C, Bates SS (2009) Mechanisms contributing to low domoic acid uptake by oysters feeding on Pseudo-nitzschia cells. I. Filtration and pseudofeces production. Aquat Biol 6:201-212

Newell RIE, Jordan SJ (1983) Preferential ingestion of organic material by the American oyster Crassostrea virginica. Mar Ecol Prog Ser 13:47-53

Novaczek I, Madhyastha MS, Ablett RF, Johnson G, Nijjar MS, Sims DE (1991) Uptake, disposition and depuration of domoic acid by blue mussels (Mytilus edulis). Aquat Toxicol 21:103-118

Palmer RE (1980) Behavioral and rhythmic aspects of filtration in the bay scallop, Argopecten irradians concentricus (Say) and the oyster, Crassostrea virginica (Gmelin). J Exp Mar Biol Ecol 45:273-295

Palmer RE, Williams LG (1980) Effect of particle concentration on filtration efficiency of the bay scallop Argopecten irradians and the oyster Crassostrea virginica. Ophelia 19: 163-174

Pocklington R, Milley JE, Bates SS, Bird CJ, de Freitas ASW, Quilliam MA (1990) Trace determination of domoic acid in seawater and phytoplankton by high performance liquid chromatography of the fluorenylmethoxycarbonyl (FMOC) derivate. Int J Environ Anal Chem 38:351-368

Riisgård HU (1988) Efficiency of particle retention and filtration rate in six species of Northeast American bivalves. Mar Ecol Prog Ser 45:217-223

Riisgård HU (2001) On measurement of filtration rates in bivalves - the stony road to reliable data: review and interpretation. Mar Ecol Prog Ser 211:275-291

Rines JEB, Donaghay PL, Dekshenieks MM, Sullivan JM, Twardowski MS (2002) Thin layers and camouflage: hidden Pseudo-nitzschia spp. (Bacillariophyceae) populations in a fjord in the San Juan Islands, Washington, USA. Mar Ecol Prog Ser 225:123-137

Round FE, Crawford RM, Mann DG (1990) The diatoms. Cambridge University Press, Cambridge

Scholin CA, Gulland F, Doucette GJ, Benson S and others (2000) Mortality of sea lions along the central California coast linked to a toxic diatom bloom. Nature 403:80-84

Shaw BA, Andersen RJ, Harrison PJ (1995) Feeding deterrence properties of apo-fucoxanthinoids from marine diatoms. I. Chemical structures of apo-fucoxanthinoids produced by Phaeodactylum tricornutum. Mar Biol 124:467-472

Shumway SE, Cucci TL, Newell RC, Yentsch CM (1985) Particle selection, ingestion, and absorption in filter-feeding bivalves. J Exp Mar Biol Ecol 91:77-92

Spatharis S, Danielidis DB, Tsirtsis G (2007) Recurrent Pseudo-

Submitted: May 15, 2008; Accepted: July 1, 2008 nitzschia calliantha (Bacillariophyceae) and Alexandrium insuetum (Dinophyceae) winter blooms induced by agricultural runoff. Harmful Algae 6:811-822

Tamburry MN, Zimmer-Faust RK (1996) Suspension feeding: basic mechanisms controlling recognition and ingestion of larvae. Limnol Oceanogr 41:1188-1197

Thessen A, Dortch Q, Soniat TM, Doucette GJ (2002) Oyster grazing on toxic and non-toxic Pseudo-nitzschia and Thalassiosira weissflogii, and Ditylum brightwellii. In: Abstracts, 94th National Shellfisheries Association meeting, Mystic, CT. J Shellfish Res 21:438

Trainer VL, Cochlan WP, Erickson A, Bill BD, Cox FH, Borchert JA, Lefebvre KA (2007) Recent domoic acid closures of shellfish harvest areas in Washington State inland waterways. Harmful Algae 6:449-459

Trainer VL, Hickey B, Bates SS (2008) Toxic diatoms. In: Walsh PJ, Smith SL, Fleming LE, Solo-Gabriele H, Gerwick WH (eds) Oceans and human health: risks and remedies from the sea. Elsevier Science Publishers, New York, p 219-237

Villac MC (1996) Synecology of the genus Pseudo-nitzschia H. Peragallo from Monterey Bay, California, USA. PhD thesis, Texas A\&M University, College Station, TX

Volcani BE (1981) Cell wall formation in diatoms. In: Simpson TL, Volcani BE (eds) Silicon and siliceous structures in biological systems. Springer-Verlag, New York, p 157-200

Waite AM, Olson RJ, Dam HG, Passow U (1995) Sugar containing compounds on the cell surfaces of marine diatoms measured using concanavalin A and flow cytometry. J Phycol 31:925-933

Ward JE, Shumway SE (2004) Separating the grain from the chaff: particle selection in suspension- and depositfeeding bivalves. J Exp Mar Biol Ecol 300:83-130

Ward JE, Targett NM (1989) Influence of marine microalgal metabolites on the feeding behavior of the blue mussel Mytilus edulis. Mar Biol 101:313-321

> Ward JE, Beninger PG, MacDonald BA, Thompson RJ (1991) Direct observations of feeding structures and mechanisms in bivalve molluscs using endoscopic examination and video image analysis. Mar Biol 111:287-291

Ward JE, Newell RIE, Thompson RJ, MacDonald BA (1994) In vivo studies of suspension-feeding processes in the eastern oyster Crassostrea virginica (Gmelin). Biol Bull 186:221-240

Ward JE, Levinton JS, Shumway SE, Cucci T (1997) Site of particle selection in a bivalve mollusc. Nature 390:131-132

Ward JE, Levinton JS, Shumway SE, Cucci T (1998a) Particle sorting in bivalves: in vivo determination of the pallial organs of selection. Mar Biol 131:283-292

Ward JE, Sanford LP, Newell RIE, MacDonald BA (1998b) A new explanation of particle capture in suspension-feeding bivalve molluscs. Limnol Oceanogr 43:741-752

> Wootton EC, Zubkov MV, Jones DH, Jones RH, Martel CM, Thornton CA, Roberts EC (2007) Biochemical prey recognition by planktonic protozoa. Environ Microbiol 9:216-222

- Wright JLC, Boyd RK, De Freitas ASW, Falk M and others (1989) Identification of domoic acid, a neuroexcitatory amino acid, in toxic mussels from eastern Prince Edward Island. Can J Chem 67:481-490

Proofs received from author(s): October 6, 2008 